\title{
Quantitative, orderly and qualitative visualisation of urban environment
}

\author{
Beata Medyńska-Gulij ${ }^{\text {a, } *, \text { Elzbieta Bielecka }}{ }^{\mathrm{b}}$, Lukasz Wielebski ${ }^{\text {a }}$ \\ ${ }^{a}$ Adam Mickiewicz University Poznan, Department of Cartography and Geomatics, Poland,bmg@amu.edu.pl \\ ${ }^{b}$ Military University of Technology, Warsaw, Department of Geospatial Information System, Institute of Geospatial Engineering and \\ Geodesy, Faculty of Civil Engineering and Geodesy, Poland, elzbieta.bielecka@wat.edu.pl \\ * Corresponding author: Beata Medyńska-Gulij, bmg@amu.edu.pl
}

Keywords: urban environment, complex geovisualisation, visual variables, topographic data

\begin{abstract}
:
The urban environment dominates the world over and some regions, such as Europe, are highly urbanized. Today, $72 \%$ of Europe's population lives in cities, towns, and suburbs. Cities are characterized by a high concentration of people, dense built-up area, highly developed transport infrastructure and services, and relatively weak and scattered urban greenery. However, the structure of the city is not uniform and the built-up area in cities becomes less compact the further away from the city center. On the outskirts of the city, built-up areas are becoming dispersed, there is more undeveloped land, the transport network is less dense, and finally the urban environment mixes with rural areas, creating the so-called transition area. The environmental dimension of city life is essential to the health and well-being of its inhabitants as well as to the quality of the surrounding territories, and therefore of great importance to decision-makers at all levels of government, from local to national and European.
\end{abstract}

Appreciating the role of maps and cartographic visualizations in supporting decision making e.g. Medyńska-Gulij et al. (2021), our research aims to demonstrate the complex geovisualization of urban area from topographic data. In particular, we focus on the visualization of buildings and surrounding elements of "grey infrastructure" such as, roads, tramways, and utilities that determine a city's layout as well as "green infrastructure", i.e. street trees, lawns, parks, community gardens, green roofs. The problem discussed in these considerations is the use of visual variables, both classical (Bertin) and new ones, as well as cartographic methods that enable the presentation of topographic data on a quantitative, ordinal, and qualitative scales. We focus mainly on the cartographic presentation of those areas of the city where multi-family buildings (block of flats) with educational facilities (such as schools or kindergartens), shops, as well as a local road, streets trees, lawns dominate. This study has become an inseparable part of the authors' research field focused mainly on modern visualization including topography and land cover e.g. Calka et al. (2016), Horbiński and Medyńska-Gulij (2017), Smaczyński et al. (2020), Wielebski et al. (2020).

Topographic data collected mainly by the National Mapping Agencies in the form of a database with the level of detail corresponding to the map scale of 1: 10,000 are used for visualization e.g. Akiyama et al. (2019). Object location, geometry (area, height), object type and distance to other topographic objects were presented in quantitative, qualitative, and ordinal scales, respectively. One of the housing estates in Poznań was selected as the test area. Complex, alternative visualizations concern open topographic data provided by the Surveyor General of Poland publicly available via the spatial data infrastructure national geoportal e.g. Izdebski et al., (20121), Bielecka and Medyńska-Gulij (2015) geoportal.gov.pl.

\section{References}

Akiyama, Y. and Sakamoto, I., 2019, The topography of the world by IN-YOU-ZU, Abstr. Int. Cartogr. Assoc., 1, 5, https://doi.org/10.5194/ica-abs-1-5-2019, 2019.

Calka, B. Bielecka, E., Zdunkiewicz, K., 2016, Redistribution population data across a regular spatial grid according to buildings characteristics. Geodesy and Cartography 65(2); 149-162, DOI: 10.1515/geocart-2016-0011.

Bielecka E., Medyńska-Gulij B., 2015, Zur Geodateninfrastruktur in Polen. Geodata Infrastructure in Poland, Kartographische Nachrichten, 65/4:201-208, DOI: 10.1007/BF03545142.

Horbiński T., Medyńska-Gulij B., 2017, Geovisualisation as a process of creating complementary visualisations: static two-dimensional, surface three-dimensional, and interactive, Geodesy and Cartography, 66, 1, 2017, 45-58, DOI: 10.1515/geocart-2017-0009. 
Izdebski, W.; Zwirowicz-Rutkowska, A.; Nowak Da Costa, J., 2021. Open data in spatial data infrastructure: the practices and experiences of Poland. International Journal of Digital Earth, https://doi.org/10.1080/17538947.2021.1952323

Medyńska-Gulij, B., Forrest, D., Cybulski, P., 2021, Modern Cartographic Forms of Expression: The Renaissance of Multimedia Cartography. ISPRS Int. J. Geo-Inf, 10, 484, DOI: 10.3390/ijgi10070484.

Smaczyński, M., Medyńska-Gulij, B., Halik, Ł., 2020, The Land Use Mapping Techniques (Including the Areas Used by Pedestrians) Based on Low-Level Aerial Imagery. ISPRS Int. J. Geo-Inf., 9(12), 754, DOI: 10.3390/ijgi9120754.

Wielebski, Ł., Medyńska-Gulij, B., Halik, D., Dickmann, F., 2020, Time, Spatial, and Descriptive Features of Pedestrian Tracks on Set of Visualizations. ISPRS Int. J. Geo-Inf. 2020, 9(6), 348, DOI: 10.3390/ijgi9060348.

geoportal.gov.pl Polish Spatial Data Infrastructure

https://mapy.geoportal.gov.pl/imap/Imgp_2.html?gpmap=gp0\&locale=en 